\title{
Leaf area controls on energy partitioning of a temperate mountain grassland
}

\author{
A. Hammerle, A. Haslwanter, U. Tappeiner, A. Cernusca, and G. Wohlfahrt \\ Institut für Ökologie, Universität Innsbruck, Sternwartestr. 15, 6020 Innsbruck, Austria \\ Received: 23 August 2007 - Published in Biogeosciences Discuss.: 11 October 2007 \\ Revised: 11 February 2008 - Accepted: 18 February 2008 - Published: 20 March 2008
}

\begin{abstract}
Using a six year data set of eddy covariance flux measurements of sensible and latent heat, soil heat flux, net radiation, above-ground phytomass and meteorological driving forces energy partitioning was investigated at a temperate mountain grassland managed as a hay meadow in the Stubai Valley (Austria). The main findings of the study were: (i) Energy partitioning was dominated by latent heat, followed by sensible heat and the soil heat flux; (ii) When compared to standard environmental forcings, the amount of green plant matter, which due to three cuts varied considerably during the vegetation period, explained similar, and partially larger, fractions of the variability in energy partitioning; (iii) There were little, if any, indications of water stress effects on energy partitioning, despite reductions in soil water availability in combination with high evaporative demand, e.g. during the summer drought of 2003.
\end{abstract}

\section{Introduction}

The partitioning of surface net radiation, that is the net balance of incident and reflected/emitted radiative energy, into the fluxes of sensible and latent heat and heat storage controls the degree of coupling between the land and the atmosphere (Oke, 1987). Thereby, surface energy partitioning determines several properties of the planetary boundary layer, such as the surface temperature (Schneider and Eugster, 2005), boundary layer height (Pan and Mahrt, 1987), cloud development and convective precipitation (Pielke, 2001; Ray et al., 2003). Since the planetary boundary layer is where humans spend most of their lives, it is of interest to understand the variability of land surface energy partitioning (e.g. Wilson et al., 2002a), the causes for this variability (e.g. Gu et al.,

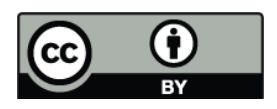

Correspondence to: A. Hammerle (Albin.Hammerle@uibk.ac.at)
2006), and also how global changes in climate and land use affect energy partitioning (e.g. Rosset et al., 2001; Beringer et al., 2005; Schneider and Eugster, 2005). In addition, there is a close link between ecosystem energy partitioning and the cycling of carbon and nutrients (Meyers, 2001; Wilson et al., 2003).

A convenient framework for analysing the surface energy partitioning is the energy balance theorem (e.g. Oke, 1987), which states that the net radiation $\left(R_{\text {net }}\right)$ of a uniform ecosystem patch equals the sum of the fluxes of latent $(L E)$, sensible $(H)$ heat and heat storage $(\Delta S)$, i.e.

$R_{\text {net }}=L E+H+\Delta S$.

Rearranging Eq. (1), expanding terms 1-3 and neglecting the contribution of heat storage in metabolic processes and above-ground phytomass to $\Delta S$ but accounting for the soil heat flux $(G$; described in detail in Sect. 2.3) yields:

$K_{\downarrow}(1-\alpha)+L_{\downarrow} \varepsilon_{s}-\varepsilon_{s} \sigma T_{s}^{4}-G$
$=\rho c_{p} g_{a H}\left(T_{S}-T_{a}\right)+\lambda g_{t V}\left(e_{s}-e_{a}\right) / P_{a}$,

where $K_{\downarrow}$ and $L_{\downarrow}$ represent the incident short- and long-wave radiation fluxes, respectively; $\alpha$ stands for the albedo, $\varepsilon_{s}$ and $T_{s}$ for the long-wave emissivity and (bulk) surface temperature, and $\sigma$ represents the Stefan-Boltzmann constant; $\rho$ and $c_{p}$ are the density and specific heat of air, $g_{a H}$ is the aerodynamic conductance for heat, and $T_{a}$ stands for air temperature at some reference height; the latent heat of vaporisation is given by $\lambda, g_{t V}$ represents the total conductance for water vapour, $e_{s}$ and $e_{a}$ refer to the saturation vapour pressure of the surface and the actual air vapour pressure, respectively, and $P_{a}$ is the air pressure.

The four main variables under biotic control in Eq. (2) are $G, \alpha, g_{a H}$ and $g_{t V}$, the latter deriving from $1 /\left(1 / g_{s V}\right.$ $+1 / g_{a V}$ ), where $g_{S V}$ and $g_{a V}$ are the surface and aerodynamic conductance for water vapour, respectively. The soil heat flux, $G$, depends on the amount of radiation absorbed

Published by Copernicus Publications on behalf of the European Geosciences Union. 
at the soil surface and is thus inversely related to the amount of above-ground plant area. The albedo, $\alpha$, depends on the amount and spatial organisation of the above-ground phytoelements and the optical properties of the vegetation and the soil surface (Ross, 1981). The aerodynamic conductance for heat and water vapour, at a given wind speed and atmospheric stability, are influenced by the amount, spatial organisation and drag of the phytoelements (Raupach, 1992; Massman, 1997). The surface conductance, $g_{s V}$, which lumps together contributions from the soil surface (Mahfouf and Noilhan, 1991) and the canopy, depends on the wetness of the surface soil, the amount of transpiring leaf area and the leaf stomatal conductance. The latter is governed in a complex fashion by the aerial environment surrounding the leaves, as well as via root-to-shoot feedback mechanisms by soil water availability (Larcher, 2001).

In summary, the amount of vegetation is a crucial biotic control on land surface energy partitioning and its influence has been studied for several ecosystems in the past (e.g. Iritz and Lindroth, 1996; Gholtz and Clark, 2002; Beringer et al., 2005; Amiro et al., 2006). In contrast to evergreen canopies which show little seasonal leaf area dynamics or natural deciduous ecosystems whose leaf area development is often closely correlated with environmental conditions, grasslands managed for hay or silage are ideal for studying the effects of changes in the amount of vegetation on energy partitioning. Because of the vegetation cuttings, which are followed by rapid plant re-growth, their canopies undergo multiple growing cycles within a single vegetation period (Wohlfahrt and Cernusca, 2002), which allows to disentangle the biotic and abiotic controls on energy partitioning under a wide range of environmental conditions.

The objective of the present paper is to study the energy partitioning of a temperate mountain grassland in the Stubai Valley (Austria) managed as a hay meadow. To this end we report six years of sensible and latent energy fluxes measured by means of the eddy covariance method and accompanying measurements of net radiation, soil heat flux, above-ground plant matter and meteorological driving forces. We hypothesise that due to rapid changes in the amount of above-ground vegetation, the amount of leaf area will play a major role in determining energy partitioning in this grassland.

\section{Material and methods}

\subsection{Site description}

The study site is located at a meadow in the vicinity of the village Neustift $\left(47^{\circ} 07^{\prime} \mathrm{N}, 11^{\circ} 19^{\prime} \mathrm{E}\right.$ ) in the Stubai Valley (Austria). The site is situated at an elevation of $970 \mathrm{~m}$ a.s.l. in the middle of the flat valley bottom. The fetch is homogenous up to $300 \mathrm{~m}$ to the east and $900 \mathrm{~m}$ to the west of the instrument tower, the dominant day and night time wind directions, respectively.
The average annual temperature is $6.5^{\circ} \mathrm{C}$, average annual precipitation amounts to $852 \mathrm{~mm}$. The vegetation has been classified as a Pastinaco-Arrhenatheretum and consists mainly of a few dominant graminoid (Dactylis glomerata, Festuca pratensis, Phleum pratensis, Trisetum flavescens) and forb (Ranunculus acris, Taraxacum officinale, Trifolium repens, Trifolium pratense, Carum carvi) species. The meadow is cut three times a year; fertilisation (solid manure) usually occurs in late autumn and occasionally after cutting (liquid manure).

The soil has been classified as a Fluvisol (FAO classification) and is approximately $1 \mathrm{~m}$ deep. Below a thin $(0.001 \mathrm{~m})$ organic layer, an A horizon, with an organic volume fraction of approximately $14 \%$, extends down to $0.02 \mathrm{~m}$, followed by the $\mathrm{B}$ horizon, which is best described as a (sandy) loam. Roots reach down to $0.5 \mathrm{~m}$, but $80 \%$ of them are concentrated in the upper $0.13 \mathrm{~m}$ of the soil.

\subsection{Eddy covariance (EC)}

EC measurements at this site are operational since March 2001 and measurements continue as of this writing. Within this paper, data from March 2001 until December 2006 are presented. Sensible $(H)$ and latent $(L E)$ heat fluxes were measured using the eddy covariance method (Baldocchi et al., 1988; Baldocchi, 2003) using the same instrumentation as and following the procedures of the EUROFLUX project (Aubinet et al., 2000). The three wind components and the speed of sound were measured by a three-dimensional sonic anemometer (R3IA, Gill Instruments, Lymington, UK). $\mathrm{H}_{2} \mathrm{O}$ mole fractions were measured by a closed-path infra-red gas analyser (Li-6262, Li-Cor, Lincoln, NE, USA). Air was sucked from the inlet, a distance of $0.1 \mathrm{~m}$ from the centre of the sensor volume of the sonic anemometer mounted at $3 \mathrm{~m}$ above ground, through a $4 \mathrm{~m}$ Teflon tube of $0.004 \mathrm{~m}$ inner diameter through a filter (Acro 50, Gelman, Ann Arbor, MI, USA) to the infra-red gas analyser at a flow rate of $91 \mathrm{~min}^{-1}$ (N035ANE, KNF Neuberger, Freiburg, Germany). The infra-red gas analyser was operated in the absolute mode, flushing the reference cell with dry $\mathrm{N}_{2}$ from a gas cylinder at $100 \mathrm{ml} \mathrm{min}^{-1}$. Raw voltage signals of the $\mathrm{H}_{2} \mathrm{O}$ mole fractions were output at $10 \mathrm{~Hz}$ to the analogue input of the sonic, where they were synchronised with the sonic signals, which were measured at $20 \mathrm{~Hz}$. All raw data were saved to a hard disc of a personal computer for postprocessing using the EdiSol software (University of Edinburgh). Half-hourly mean eddy fluxes of latent and sensible heat were calculated as the covariance between the turbulent departures from the mean of the vertical wind speed and the $\mathrm{H}_{2} \mathrm{O}$ mixing ratio and the sonic temperature $\left(T_{S}\right)$, respectively, using the post-processing software EdiRe (University of Edinburgh). Means and turbulent departures there from were calculated by Reynolds (block) averaging. The tubeinduced time delay of the $\mathrm{H}_{2} \mathrm{O}$ signal (approx. 1.2 s) was determined by optimising the correlation coefficient with the 
vertical wind velocity (McMillen, 1988) within a given time window. A three-axis co-ordinate rotation was performed aligning the co-ordinate system's vector basis with the mean wind streamlines (Kaimal and Finnigan, 1994). Frequency response corrections were applied to raw eddy fluxes accounting for low-pass (sensor separation, dynamic frequency response, scalar and vector path averaging, frequency response mismatch and the attenuation of concentration fluctuations down the sampling tube) and high-pass filtering following Moore (1986) and Aubinet et al. (2000). Experimentally derived frequency response correction factors, according to Aubinet et al. $(2000,2001)$, were used to calibrate and assess the validity of the theoretical low-pass filtering correction method, as described in detail in Wohlfahrt et al. (2005). Finally, the sensible heat flux was corrected for the effects of air humidity following Schotanus et al. (1983).

Net fluxes of sensible and latent heat were calculated as the sum of the corrected vertical eddy term and the storage fluxes, the latter being estimated from the time-rate-ofchange of the $\mathrm{H}_{2} \mathrm{O}$ concentration and air temperature at the reference height, which in a previous comparison with a profiling system was found to be sufficiently accurate. Negative fluxes represent transport from the atmosphere towards the surface, positive ones the reverse.

\subsection{Ancillary data}

Supporting meteorological measurements of relevance to this study included albedo, net- $\left(R_{\text {net }}\right)$ and global radiation $\left(R_{g}\right)$ by separately measuring the up- and downward longand short-wave radiation components (CNR-1, Kipp \& Zonen, Delft, The Netherlands), air temperature $\left(T_{\text {air }}\right)$ and humidity $(\mathrm{RH})$ at $2 \mathrm{~m}$ height and soil temperature $\left(T_{\text {soil }}\right)$ at $0.05 \mathrm{~m}$ depth, measured by the means of a combined temperature/humidity sensor (RFT-2, UMS, Munich, Germany) and an averaging soil thermocouple probe (TCAV, Campbell Scientific, Logan, UT, USA), respectively, soil heat flux $(G)$ measured by the means of heat flux plates ( 3 replicates at $0.05 \mathrm{~m}$ depth (HFP01, Hukseflux, Delft, The Netherlands)), corrected for the change in heat storage above that depth by using the calorimetric method (Sauer and Horten, 2005), soil water content (SWC) (ML2x, Delta-T Devices, Cambridge, UK) and precipitation (Precip) (52202, R. M. Young, Traverse City, MI, USA). Volumetric soil water content was converted to plant available water (PAW, \%) by normalising between the water content at field capacity (100\% PAW) and the wilting point $(0 \%$ PAW), which were determined from water retention curve analysis (Hillel, 1980).

Because green, transpiring stems make up an appreciable fraction of the above-ground biomass (Wohlfahrt et al., 2001), we use the green area index (GAI, $\mathrm{m}^{2} \mathrm{~m}^{-2}$ ), which comprises leaves and green stems, instead of the commonly used leaf area index for quantifying the amount of transpiring surface. The GAI was assessed (i) in a destructive fashion by clipping of square plots of $0.09 \mathrm{~m}^{2}$ (3-5 replicates) and sub- sequent plant area determination (Li-3100, Li-Cor, Lincoln, NE, USA) and (ii) from measurements of maximum canopy height $(h, \mathrm{~m})$ which was related to destructively measured GAI using the following relationship:

$\mathrm{GAI}=\frac{11.07 h}{0.64+h} \quad r^{2}=0.89$

Continuous time series of the GAI were derived by fitting sigmoid and quadratic functions to measured data separately for each growing phase before and after the third cutting, respectively.

\subsection{Data analysis}

Half-hourly flux data were screened for validity by removal of time periods with (i) the $\mathrm{H}_{2} \mathrm{O}$ and the temperature signal outside a specific range, (ii) the coefficient of variation for $\mathrm{H}_{2} \mathrm{O}$ concentration, temperature and pressure within the IRGA outside a specific range, (iii) the third rotation angle exceeding $\pm 10^{\circ}$ (McMillen, 1988), (iv) the stationarity tests for latent and sensible heat fluxes exceeding $60 \%$ (Foken and Wichura, 1996), (v) the deviation of the integral similarity characteristics larger than 60\% (Foken and Wichura, 1996) and (vi) the maximum of the footprint function (Hsieh et al., 2000) outside the boundaries of the meadow (Novick et al., 2004).

For calculating midday average values of energy fluxes, the diurnal course of these fluxes was quantified using the diurnal centroid method (Wilson et al., 2003). The centroids for the latent and sensible heat flux were found to occur between 12:15 and 13:30 CET and between 10:45 and 12:45 CET, respectively. Based on these findings, the period for calculating the mean midday metrics of $\beta$ (Bowenratio, $H / L E), L E / R_{\text {net }}, H / R_{\text {net }}, G / R_{\text {net }}$ and $\alpha$ was chosen from 10:00 CET until 14:00 CET. In the case of the albedo $(\alpha)$, this procedure had the additional benefit of minimizing the effect of low solar angles (Li et al., 2006).

Closure of the energy balance, i.e. matching the sum of $L E$ and $H$ to the difference between $R_{\text {net }}$ and G, is often considered to be an independent approach to check the overall performance of the EC system (Wilson et al., 2002b). The gap in energy balance closure at the study site in Neustift is on average $21 \%$ (range: $32 \%$ (2003)-14\% (2001)) and is thus within the range reported for 22 FLUXNET sites in Wilson et al. (2002b). Presuming that both turbulent fluxes are underestimated by similar relative fractions (Wilson et al., 2002a), energy balance closure was achieved by increasing the turbulent fluxes by the mean imbalance, thereby preserving the Bowen-ratio (Twine et al., 2000).

\section{Results}

\subsection{Climatic conditions}

As shown in Fig. 1, global radiation, $\mathrm{R}_{g}$, ranged from daily maximum values close to $30 \mathrm{MJ} \mathrm{m}^{-2} \mathrm{~d}^{-1}$ in 

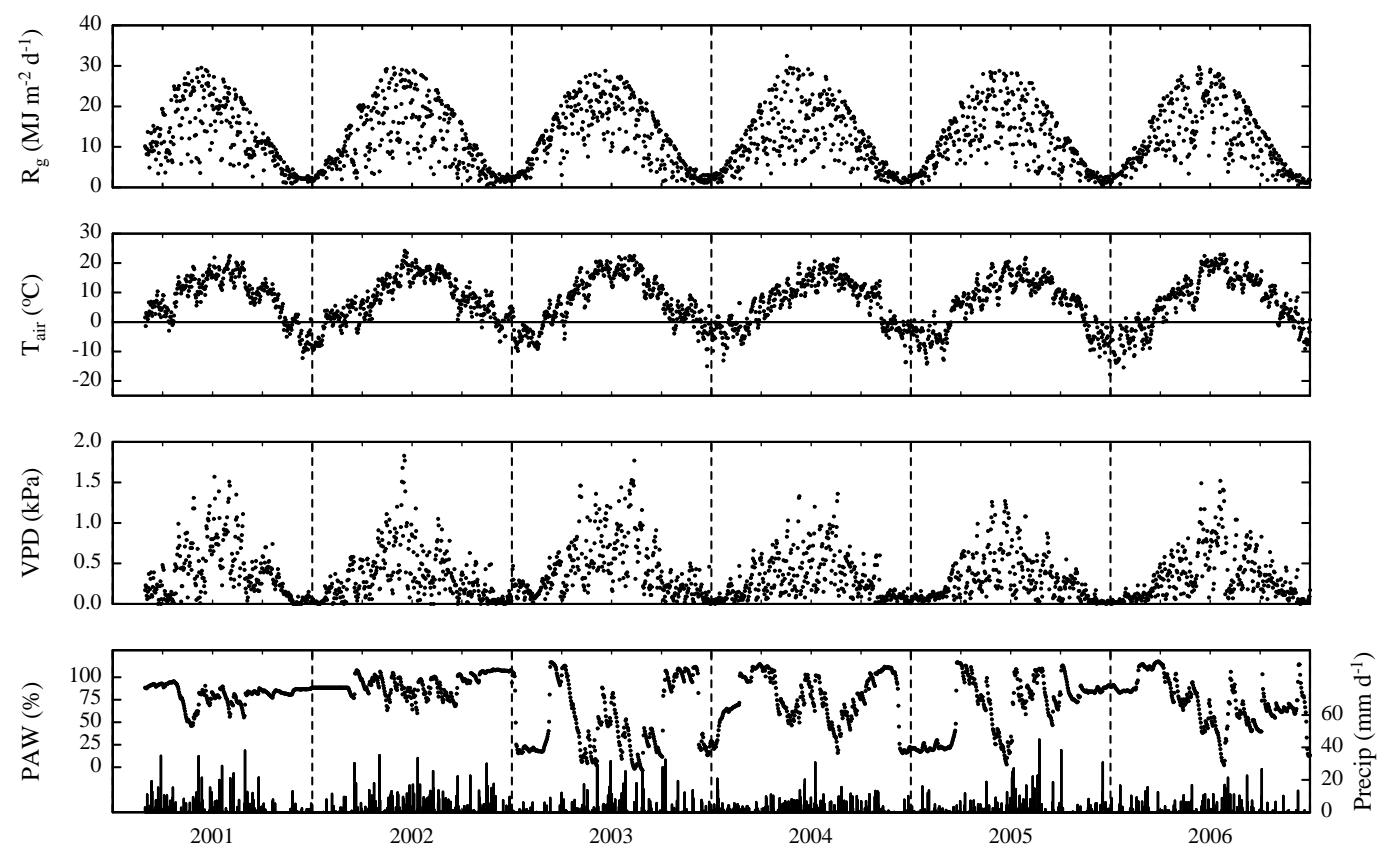

Fig. 1. Seasonal and inter-annual variability (March 2001-December 2006) of daily sums of global radiation $\left(R_{g}\right)$ and precipitation (Precip; vertical bars) and daily averages of air temperature, vapour pressure deficit ( $T_{\text {air }}$ and VPD, at $2 \mathrm{~m}$ above ground) and plant available water (PAW; closed symbols; at $0.05 \mathrm{~m}$ soil depth).

June to minimum values around $0.5 \mathrm{MJ} \mathrm{m}^{-2} \mathrm{~d}^{-1}$ in December. The year with the lowest annual $R_{g}$ was 2004 (4156 $\mathrm{MJ} \mathrm{m}^{-2} \mathrm{y}^{-1}$ ), the highest solar radiation input $\left(4526 \mathrm{MJ} \mathrm{m}^{-2} \mathrm{y}^{-1}\right)$ occurred in 2003 , when daily $R_{g}$ remained below $10 \mathrm{MJ} \mathrm{m}^{-2} \mathrm{~d}^{-1}$ for only 22 days during the period from April until September (2001-2006 average: 32 days; Fig. 1). 2003 was also the year with the highest annual mean VPD of $0.43 \mathrm{kPa}(2001-2006$ average: $0.35 \mathrm{kPa})$ and the lowest mean plant available water (PAW; averaged over the period of April to September) of 40\% (2001-2006 average: 69\%). Following Granier et al. (1999) in assuming water stress to occur when PAW drops below 40\%, 109 days with water stress were counted in the period of April until September of 2003, for 2004-2006 this value ranged from 17-35 days, while not a single day with PAW $<40 \%$ occurred in 2001 and 2002 (Fig. 1). Average daily air temperatures varied between $24^{\circ} \mathrm{C}$ and $-18^{\circ} \mathrm{C}$. The warmest year was 2002 with an annual average of $7.7^{\circ} \mathrm{C}$, the coldest year was 2005 with an annual average of $5.6^{\circ} \mathrm{C}$ (1980-2002 average: $6.5^{\circ} \mathrm{C}$ ). With mean monthly temperatures exceeding $18^{\circ} \mathrm{C}$, June and August 2003 and July 2006 were the hottest months investigated, while the coldest month was January 2006 with an average monthly temperature of $-7.7^{\circ} \mathrm{C}$ (Fig. 1). Precipitation varied from $582 \mathrm{~mm} \mathrm{y}^{-1}$ in 2006 to $984 \mathrm{~mm} \mathrm{y}^{-1}$ in 2002 (1980-2000 average: $852 \mathrm{~mm} \mathrm{y}^{-1}$ ). Snow cover duration (Fig. 2) ranged from 93 days (2002) to 128 days (2001). Snow melting dates varied from 7 (2003) to 30 March (2005), the permanent winter snow cover established between 18 November (2005) and 20 December (2004).

\subsection{Canopy development and albedo}

The amount of GAI ranged from close to nil after snow melt, up to $7.6 \mathrm{~m}^{2} \mathrm{~m}^{-2}$ on the verge of cutting (Fig. 2). The meadow was cut three times a year, the cuts taking place between 2 and 16 June, 24 July and 12 August, and 21 September and 28 October. Cutting reduced the GAI down to 0.5$2.0 \mathrm{~m}^{2} \mathrm{~m}^{-2}$ (Fig. 2).

During periods of snow cover almost all shortwave radiation was reflected by the white surface and midday means of the albedo $(\alpha)$ varied between $0.8-1.0$ (Fig. 2). During the snow-free (vegetation) period $\alpha$ varied with GAI in an asymptotic fashion $\left(\alpha=0.1765 \mathrm{GAI}^{0.1295}, R^{2}=0.40\right.$, $p<0.001), 90 \%$ of the maximum vegetation period $\alpha(0.23$; midday mean) being reached at a GAI of $3.4 \mathrm{~m}^{2} \mathrm{~m}^{-2}$ (Figs. 2 and 3). Effects of changing solar angles over the course of the vegetation period were not evident (data not shown).

\subsection{Seasonal variation in energy partitioning}

During most of the winter time, energy fluxes were minimal $-R_{\text {net }}$ and $H$ were slightly negative, while $G$ and $L E$ undulated around zero (Fig. 4). With the initiation of snowmelt, $R_{\text {net }}$ quickly increased and the mean monthly diurnal courses ranged from $-70 \mathrm{~W} \mathrm{~m}^{-2}$ up to $520 \mathrm{~W} \mathrm{~m}^{-2}$ during the vegetation period, closely following global radiation $\left(R_{g}, R_{\text {net }}=0.68 R_{g}-40.82, R^{2}=0.96, p<0.001\right)$. Due to the low canopy height and the absent snow cover, $G$ increased rapidly after snowmelt, consuming up to $25 \%$ of $R_{\text {net }}$ and 

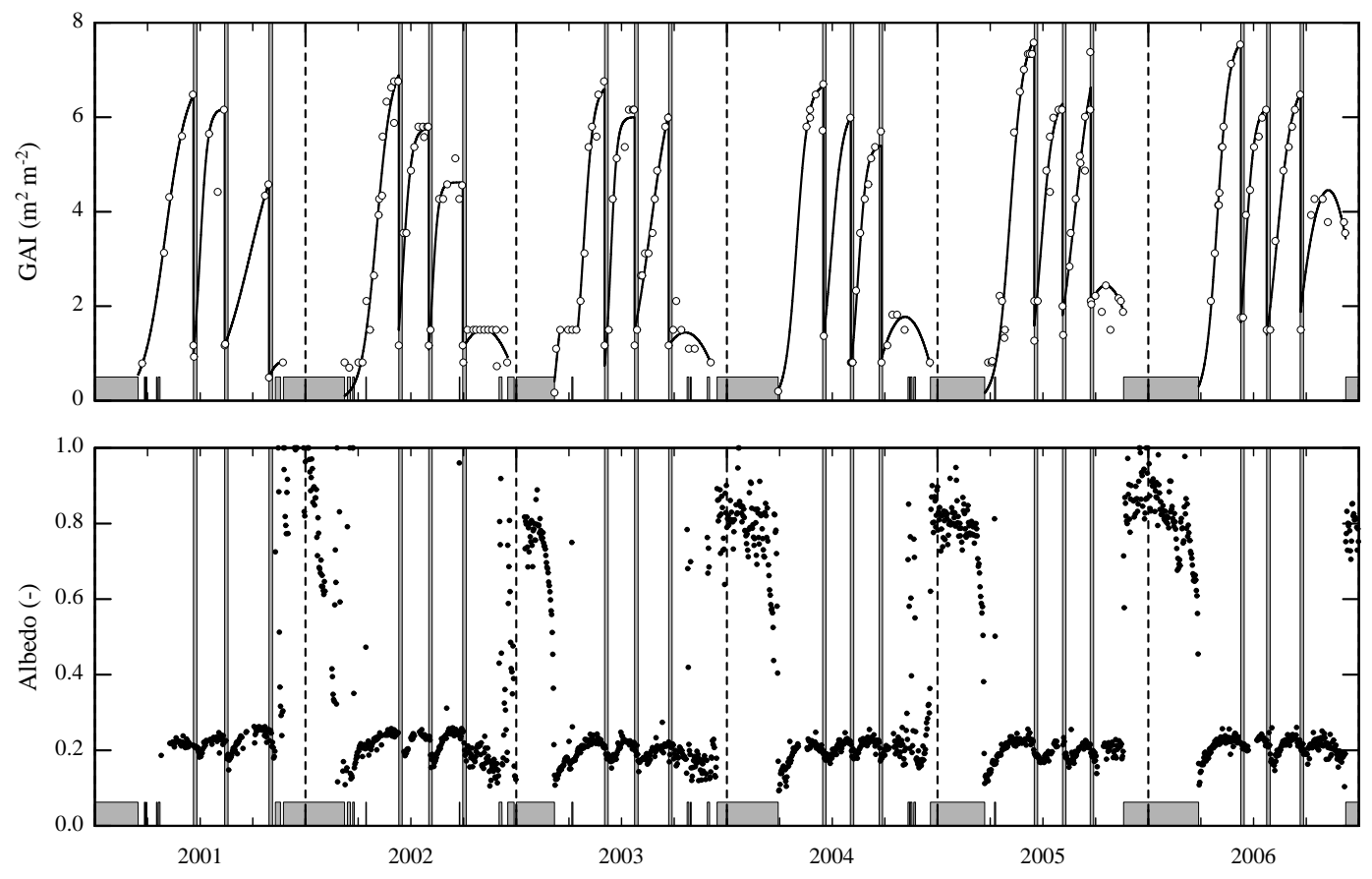

Fig. 2. Seasonal and inter-annual variability (March 2001-December 2006) of green area index (GAI; measured data (open circles) and sigmoid/quadratic fits (lines)) and albedo (midday means). Snow cover periods and cutting events are indicated by grey horizontal and vertical bars respectively.

reaching maximum monthly averaged values of $135 \mathrm{~W} \mathrm{~m}^{-2}$ in March/April (Fig. 4). During the vegetation period, $H$ ranged from $-50 \mathrm{~W} \mathrm{~m}^{-2}$ up to $170 \mathrm{~W} \mathrm{~m}^{-2}$ (90\% of data between $10 \%$ and $44 \%$ of $R_{\text {net }}$ (midday means)) and LE ranged from $-10 \mathrm{~W} \mathrm{~m}^{-2}$ to $440 \mathrm{~W} \mathrm{~m}^{-2}$ (90\% of data between $35 \%$ and $73 \%$ of $R_{\text {net }}$ (midday means)) as shown in Figs. 4 and 5. Overall $L E$ was the dominating energy flux over the course of the vegetation period (54\% of $R_{\text {net }}$ (midday means)) and midday means of $\beta$ amounted on average to 0.55 , with $90 \%$ of the values ranging between 0.04 and 1.06 (vegetation period only). Because $H$ increased faster than $L E$ in spring and sustained high values longer than $L E$ in autumn (Figs. 4 and 5), midday means of $\beta$ exhibited a concave shape with $\beta$ being one or higher during spring and autumn and close to 0.15 in summer (Fig. 5). Deviations from these general patterns were caused by the cutting events, which led to sustained increases in G (e.g. in 2006; Fig. 5), but also increased the fraction of $H$ at the expense of $L E$ for a few days after cutting (e.g. first cut 2001 and 2002, second cut 2006; Fig. 5).

\subsection{Biotic controls on energy partitioning}

The dependence of energy partitioning on GAI is shown in Fig. 6. At low GAI values, $H, L E$ and $G$ shared comparable fractions of $R_{\text {net }}(25 \%-38 \%$ (midday means)), but as the GAI increased the three energy flux components exhibited different trends: The midday mean fraction of $L E$ increased in a saturation-type fashion with increasing GAI $\left(R^{2}=0.35\right.$,

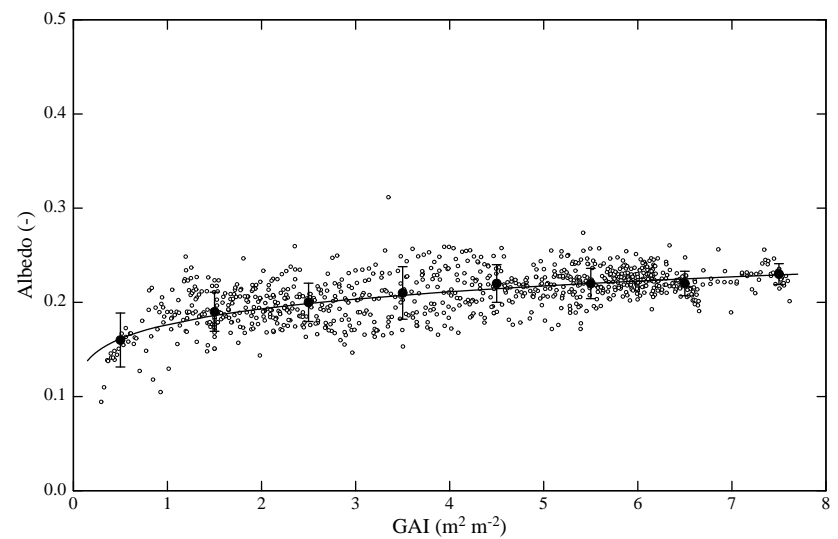

Fig. 3. Green area index (GAI) vs. albedo ( $\alpha$; midday means). Closed symbols show bin averaged data for GAI classes of $1 \mathrm{~m}^{2} \mathrm{~m}^{-2}$, where error bars refer to \pm 1 standard deviation. The line indicates an asymptotic fit to the raw data $\left(\alpha=0.1765 \mathrm{GAI}^{0.1295}\right.$, $\left.R^{2}=0.40, p<0.001\right)$.

$p<0.001), G$ decreased $\left(R^{2}=0.32, p<0.001\right)$, while $H$ decreased initially and then increased again at high GAI values $\left(R^{2}=0.10, p<0.001\right.$; Fig. 6$)$. The canopy drag coefficient $\left(C_{d}=u_{*}^{2} u^{-2}\right)$, and thus the aerodynamic conductance $\left(g_{a}\right)$, increased within increasing GAI $\left(C_{d}=0.0058 \mathrm{e}^{0.1087 \mathrm{GAI}}\right.$, $\left.R^{2}=0.14, p<0.001\right)$. 


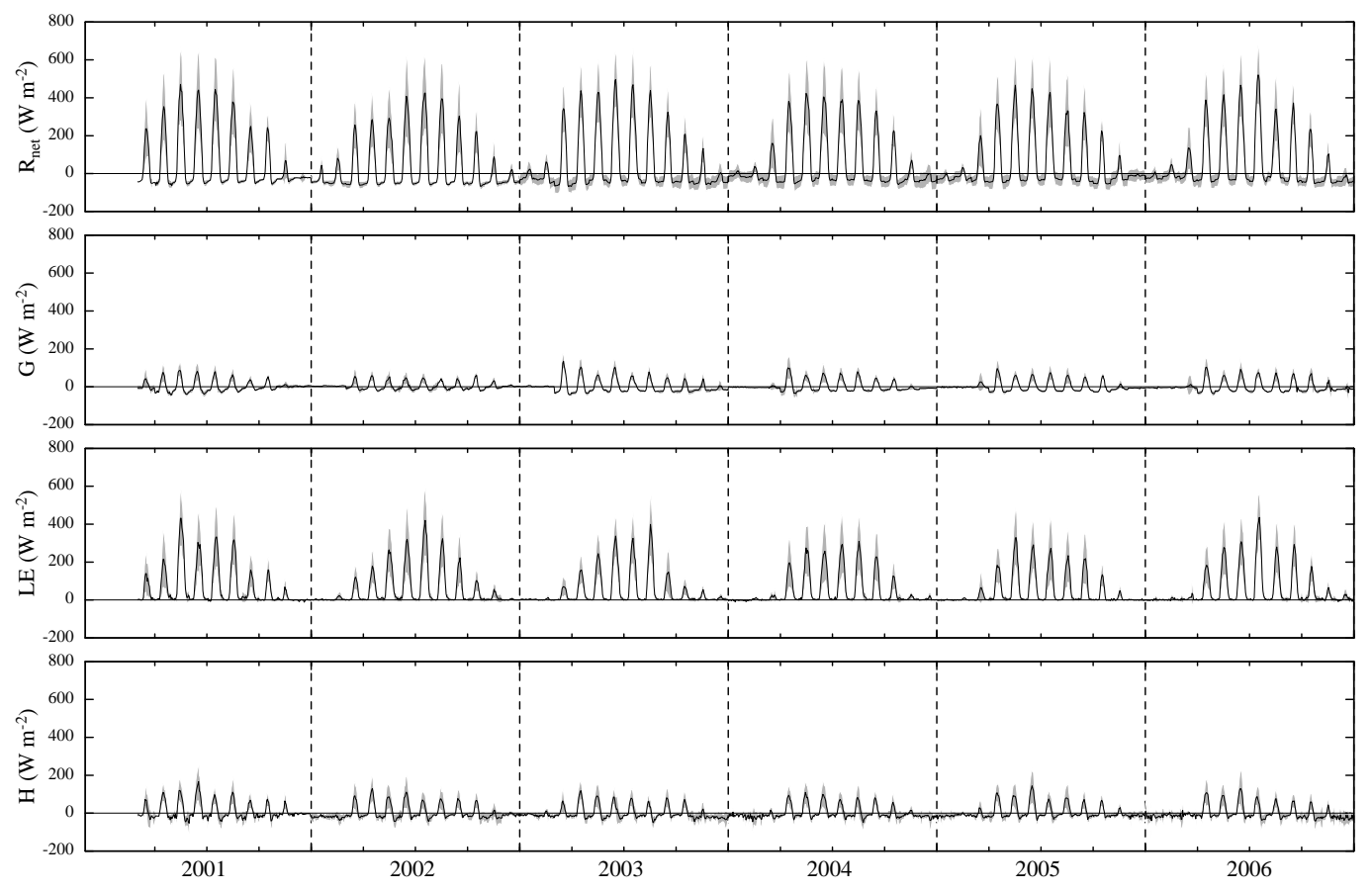

Fig. 4. Mean monthly diurnal courses of net radiation $\left(R_{\text {net }}\right)$, ground heat flux $(G)$, latent $(L E)$ and sensible heat flux $(H)$. The latter two were increased by the mean imbalance of $21 \%$ preserving the Bowen-ratio. Shaded areas refer to \pm 1 standard deviation.

Table 1. Coefficients of determination $\left(R^{2}\right)$ of linear regressions of the fractions of latent heat $(L E)$, sensible heat $(H)$ and soil heat flux ( $G$; dependent variables) against solar radiation $\left(R_{g}\right)$, air temperature $\left(T_{\text {air }}\right)$, friction velocity $\left(u_{*}\right)$, plant available water (PAW) and vapour pressure deficit (VPD; independent variables). Values in parentheses show the coefficients of determination after the influence of GAI, as shown in Fig. 6, has been removed.

\begin{tabular}{llll}
\hline & $L E$ & $H$ & $G$ \\
\hline$R_{g}$ & $0.12(0.10)$ & $0.13(0.12)$ & $0.00(0.01)$ \\
$T_{\text {air }}$ & $0.44(0.31)$ & $0.40(0.31)$ & $0.02(0.01)$ \\
$u_{*}$ & $0.08(0.04)$ & $0.01(0.00)$ & $0.10(0.06)$ \\
PAW & $0.21(0.05)$ & $0.04(0.01)$ & $0.16(0.02)$ \\
VPD & $0.30(0.29)$ & $0.33(0.33)$ & $0.00(0.02)$ \\
\hline
\end{tabular}

\subsection{Abiotic controls on energy partitioning}

Among the environmental influence factors considered (Table 1), air temperature $\left(T_{\text {air }}\right)$ and vapour pressure deficit (VPD) explained around 40 and $30 \%$ of the variability in $L E / R_{\text {net }}$ and $H / R_{\text {net }}$, respectively ( $\left.p<0.001\right)$, but were highly correlated with each other $\left(R^{2}=0.82, p<0.001\right)$. Removing the influence of the GAI on $L E / R_{\text {net }}$ (as depicted in Fig. 6) reduced the correlation between $T_{\text {air }}$ and $L E / R_{\text {net }}(p<0.001)$, while little change was observed for VPD $(p<0.001$, Table 1). None of the environmental parameters considered explained more than $16 \%$ of the variability in $G / R_{\text {net }}$, which reduced to $6 \%$ after removing the influence of GAI (Table 1). The ratio of $H$ to $L E, \beta$, decreased roughly exponentially with increasing VPD, irrespective of soil water availability (Fig. 7).

\section{Discussion}

We have quantified the fluxes of sensible and latent heat, the soil heat flux, net radiation, above-ground phytomass and the major environmental driving forces at a temperate mountain grassland in the Stubai Valley (Austria) over a period of six years. The study site, managed as a hay meadow, is cut three times per year, causing significant temporal dynamics in vegetation cover. Based on these rapid changes in the amount of vegetation, we hypothesised that the partitioning of net radiation into the fluxes of sensible and latent heat and the soil heat flux would be mainly under biotic control (through the amount of aboveground vegetation) and that abiotic (environmental) controls would be of secondary importance for energy partitioning.

The amount of green area (GAI) was equally, and in the case of $\mathrm{G}$ even more, important for explaining the observed variability in energy partitioning as the investigated environmental driving forces (Fig. 6, Table 1): The fraction of $R_{\text {net }}$ consumed in $L E$ increased with increasing GAI in an asymptotic fashion from initially $37 \%$ up to $61 \%$. Increases in $L E$ with increasing leaf areas have been observed for crops (Iritz and Lindroth, 1996) and grasslands 

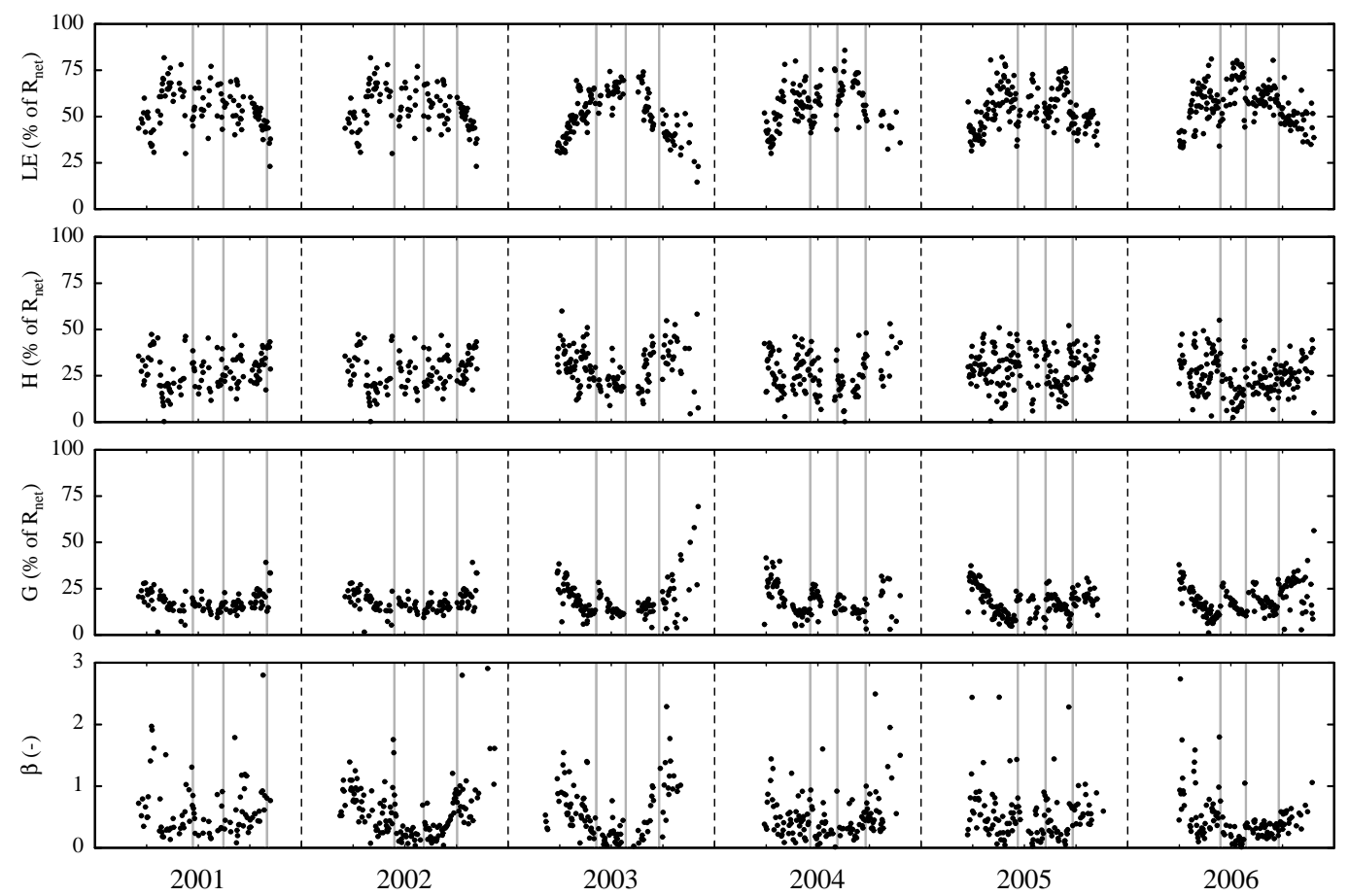

Fig. 5. Seasonal and inter-annual variability (March 2001-December 2006) of midday means of latent heat flux $(L E)$, sensible heat flux $(H)$ and ground heat flux $(G)$ expressed relative to net radiation $\left(R_{\text {net }}\right)$ and Bowen-ratio $(\beta)$. Ratios of $H / R_{\text {net }}$ and $L E / R_{\text {net }}$ were increased in order to meet energy balance closure, preserving the Bowen-ratio. Vertical grey bars indicate cutting events.

(Rosset et al., 1997; Li et al., 2006) and are generally attributed to increases in surface conductance, which comprises contributions from both the soil surface and the canopy (i.e. under dry conditions mostly stomatal) conductance. The saturation of LE with respect to GAI at high values of GAI has two probable causes: first, the contribution of the soil surface to total ecosystem evapotranspiration decreases with increasing leaf area (Schulze et al., 1996; Li et al., 2006; Saigusa et al., 1998; Wilson and Baldocchi, 2000). According to Rutter (1975) soil evaporation makes up around $10 \%$ of total evapotranspiration in reasonably closed canopies, while Körner (1977) reports soil evaporation contributions of up to $30 \%$ for low-stature Alpine grassland ecosystems with low canopy cover. Second, the fraction of shaded leaves, which receive only diffuse light, increases with increasing LAI (Ross, 1981). In contrast to sunlit leaves, the photosynthesis of shaded leaves is usually limited by light and not by the partial pressure of $\mathrm{CO}_{2}$ (Wohlfahrt et al., 1999). $\mathrm{CO}_{2}$ enters leaves through the same pathway water vapour is lost, the stomata (Larcher, 2001) and in order to avoid excessive water loss, shaded leaves thus generally reduce stomatal conductance and thus transpiration (Mooney et al., 1983; Bunce, 2000; Matsumoto et al., 2005). An alternative explanation of the saturation-type response of $L E / R_{\text {net }}$ with GAI would be that the high evapotranspiration rates lead to an increase in vapour pressure and thus a decrease of the evaporative demand, which in turn feeds back on evapotranspiration (e.g. Freedman et al., 2001). However, as shown in Fig. 7, high evapotranspiration rates (i.e. low bowen-ratios) occur during times with high VPD. Apparently, the evaporated water is transported away from the surface by efficient turbulent mixing, preventing low VPDs and their above-mentioned negative feedback on $L E$.

The fraction of net radiation partitioned into $\mathrm{G}$ decreased from $25 \%$ at low GAI values to $9 \%$ at high GAIs (Fig. 6), a trend which is in accordance with findings from various ecosystems (Song et al., 1997; Huang and Lyons, 1995; Shen et al., 2004; Li et al., 2005). According to Yang et al. (1999) there are several explanations for the reduction of $G$ : the increasing vegetation cover reduces solar energy received by the ground surface, leading to lower amplitudes of the temperature wave in the soil and thereby reducing $G$. Another cause quoted by Yang et al. (1999) is heat storage in the canopy layer, which we did not account for in our energy balance assessment, which increases with increasing aboveground phytomass. According to Iritz and Lindroth (1996) this may lead to a phase shift of the peak of $G$ towards the afternoon with increasing ground cover, a finding corroborated in the present study (data not shown). Yang et al. (1999) also discuss the role of within-canopy thermal radiation: sunlit leaves at the top of the canopy receive more radiation than shaded leaves close to the ground, which remain cooler and emit less thermal radiation to the soil. In addition, the energy storage term in the soil layer above the heat flux plates also 


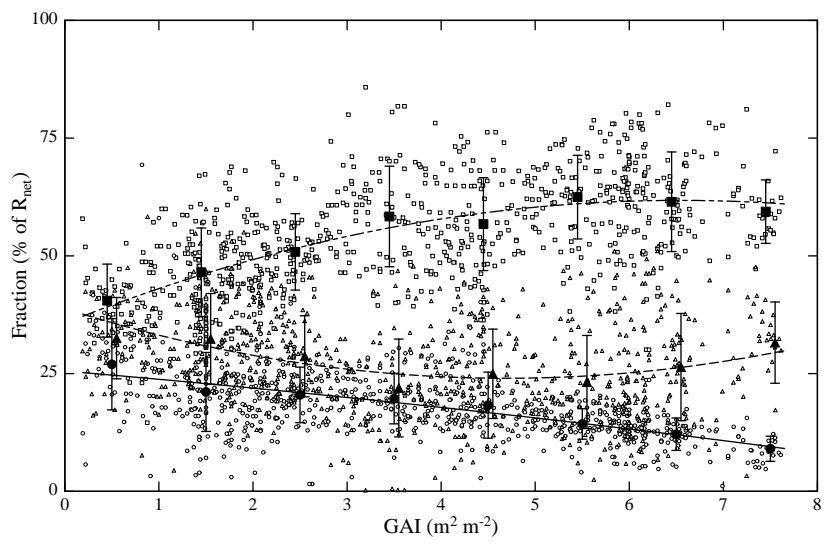

Fig. 6. Green area index $(\mathrm{GAI})$ vs. fractions of net radiation $\left(R_{\text {net }}\right)$ of latent heat flux ( $L E$; squares; $\left.\mathrm{y}=-0.61 \mathrm{x}^{2}+7.98 \mathrm{x}+35.68\right)$, sensible heat flux $\left(H\right.$; triangles; $\left.\mathrm{y}=0.67 \mathrm{x}^{2}-6.29 \mathrm{x}+38.78\right)$ and ground heat flux $\left(G\right.$; circles; $\left.\mathrm{y}=-0.06 \mathrm{x}^{2}-1.69 \mathrm{x}+25.54\right)$. Ratios of $H / R_{\text {net }}$ and $L E / R_{\text {net }}$ were increased in order to meet energy balance closure, preserving the Bowen-ratio. Open symbols refer to midday means, closed symbols to bin averaged data $\left(1 \mathrm{~m}^{2} \mathrm{~m}^{-2}\right.$ bins). Lines show best fits to the raw data. Error bars refer to \pm 1 standard deviation of bin-averaged data.

decreases with increasing LAI (Iritz and Lindroth, 1996). Furthermore, the boundary layer resistance for heat increases with decreasing wind speed (Monteith and Unsworth, 1990). Wind speed decreases within the canopy and is thus lower under a vegetated surface than over bare soil. Hence the soil surface conductance for heat and water vapour decrease with increasing GAI, reducing the exchange of sensible and latent heat at the soil surface. Other factors explaining some of the scatter around the correlation between $G$ and GAI are the SWC (Table 1), which is positively correlated with $G$ (Santanello and Friedl, 2003).

The fraction of $R_{\text {net }}$ used for $H$ initially decreased with increasing GAI up to around GAI $=4-5 \mathrm{~m}^{2} \mathrm{~m}^{-2}$; at higher values the trend reversed (Fig. 6). $H / R_{\text {net }}$ decreasing with GAI is somewhat unexpected, as the drag coefficient, which is directly related to the aerodynamic conductance, $g_{a}$, increased with increasing GAI, a finding supported by several other studies (e.g. Beringer et al., 2005; Hall, 2002). According to Eq. (2), an increase in $g_{a}$ should yield an increase in $H$, provided that the difference between surface and air temperature remains constant. We thus conclude that the decrease in $H$ with increasing GAI reflects a decrease of the surface relative to air temperature caused by the vigorously transpiring canopy and that $H$ represents some sort of remainder term in the energy balance.

The albedo plays an important role for energy partitioning, as it determines the amount of energy available to the ecosystem. The portion of reflected short wave radiation can be influenced by many factors, such as changes in land cover types (Forster et al., 2007), phenology (Song, 1999),

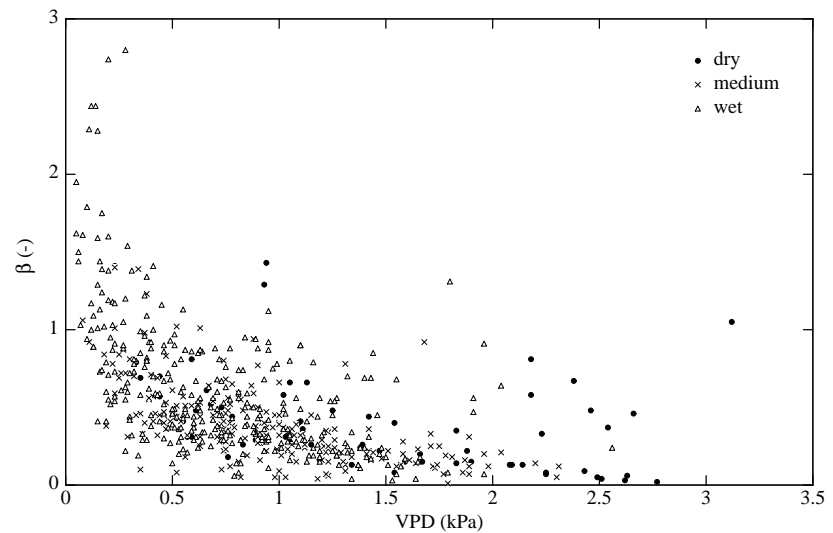

Fig. 7. Midday means of Bowen-ratio $(\beta)$ vs. vapour pressure deficit (VPD) for three classes of plant available water (PAW; dry $\leq 0.36<$ medium $\leq 0.77<$ wet $)$.

canopy structure (Rosset et al., 2001), tissue chemistry, atmospheric conditions, solar and viewing geometry (Asner, 1998; Oguntunde and van de Giesen, 2004). Beside the presence of snow cover, the amount of GAI was found to be of dominating influence for the albedo during the vegetation period. The albedo increased with GAI in a saturation type fashion, resulting in maximum values of 0.23 , which is in accordance with other grasslands studies (e.g. Rosset et al., 1997; Li et al., 2006; Song, 1999). The dependency of albedo on GAI can be explained by two factors. (i) The steep increase of the albedo at low GAI values results from the decreasing contribution of the soil to the canopy reflectance (Rosset et al., 2001; Asner, 1998; Oguntunde and Van de Giesen, 2004). According to Goudrian (1977) the effect of the soil on the canopy reflectance is practically negligible at LAI $>2 \mathrm{~m}^{2} \mathrm{~m}^{-2}$. (ii) There is an increase in the canopy reflectance in the near-infra-red (NIR) band with increasing GAI, which diminishes in importance with increasing GAI, whereas reflectance in the visible region is sensitive to LAI only at very low values (LAI $<1.0 \mathrm{~m}^{2} \mathrm{~m}^{-2}$; Asner, 1998), resulting in a saturation-type relationship. Scatter around this trend can be further explained by factors like changes in sky turbidity, leaf angle distribution (Asner, 1998) and phenology (Rosset et al., 2001). The decrease of albedo at low GAI (Fig. 3) contrasts other studies (e.g. Li et al., 2000), where albedo has been found to increase as canopy cover decreases. The likely cause for this difference is soil reflectance, which apparently is relatively low (i.e. the soil appears dark) at our site when the GAI is small, that is during early spring when soils are still water-saturated (Monteith and Unsworth, 1990) after snow melt (Fig. 1).

The dominating abiotic factor, controlling the energy availability, as well as energy partitioning was the presence/absence of a snow cover. Beside low air temperatures during winter, also the high reflectance of the white surface (Fig. 2), led to slightly negative $R_{\text {net }}$ values during these 
times of the year (Fig. 4). Accordingly small were $G, H$ and $L E$; the latter two, in addition, were inherently noisy due to the combination of a stable stratification of the atmosphere and low wind speeds.

The two abiotic factors most frequently quoted for affecting energy partitioning are soil moisture, and thus the ability of plants to take up water, as well as the vapour pressure deficit (VPD), a measure of the evaporative demand of the atmosphere (Gu et al., 2006; Li et al., 2007). Low soil moisture and/or high VPD lead to stomatal closure (Larcher, 2001) and thus a reduction in the latent heat flux, which most often is compensated by increases in the flux of sensible heat (Valentini et al., 1995; Grant et al., 2006). Despite high VPDs and reductions in soil moisture close to the wilting point (Fig. 1), in particular during 2003 when severe water stress was diagnosed for several forest and agricultural ecosystems in Europe (Granier et al., 2007), no indication of major shifts in energy partitioning was found in the present study: The Bowen-ratio $(\beta, H / L E)$ decreased with increasing VPD irrespective of soil water availability, which indicates that LE was not restricted by low soil water availability and high evaporative demand (Fig. 7, Table 1).

At present we can offer two explanations for this lack of water stress symptoms despite very low soil water contents: First, the 40\% PAW threshold as an indicator of water stress, proposed and tested by Granier et al. $(1999,2007)$ for trees, may simply not be applicable to grassland ecosystems, which differ physiologically and structurally considerably from forest ecosystems. Second, while $80 \%$ of the roots are confined to the $0-0.12 \mathrm{~m}$ soil layer, plants may continue taking up water from deeper in the soil when the upper soil dries out, causing our soil water content measurements at $0.05 \mathrm{~m}$ soil depth to underestimate true soil water availability (Miller et al., 2007). Supporting evidence for this hypothesis derives from soil water content measurements at $0.2 \mathrm{~m}$ soil depth during 2006, which showed that even when the soil water content at $0.05 \mathrm{~m}$ soil depth dropped below $5 \%$, it remained at about $40 \%$ at $0.2 \mathrm{~m}$ depth. Accordingly, Granier's $40 \%$ PAW threshold for the onset of water stress at $0.05 \mathrm{~m}$ relates to $\mathrm{PAW}=55 \%$ at $0.2 \mathrm{~m}$.

Acknowledgements. This research was supported by the Austrian National Science Fund (FWF) under contract P17560, the Tyrolean Science Fund under contract UNI-404/33, and the Austrian Academy of Sciences through a DOC fellowship to A. Hammerle. We would like to thank A. Wolf and an anonymous referee for their constructive comments on the manuscript.

Edited by: J. Kesselmeier

\section{References}

Amiro, B. D., Barr, A. G., Black, T. A., Iwashita, H., Kljun, N., McCaughey, J. H., Morgenstern, K., Murayama, S., Nesic, Z., Orchansky, A. L., and Saigusa, N.: Carbon, energy and water fluxes at mature and disturbed forest sites, Saskatchewan, Canada, Agr. Forest Meteorol., 136, 237-251, 2006.
Asner, G. P.: Biophysical and biochemical sources of variability in canopy reflectance, Remote Sens. Environ., 64, 234-253, 1998.

Aubinet, M., Grelle, A., Ibrom, A., Rannik, Ü., Moncrieff, J., Foken, T., Kowalski, A. S., Martin, P. H., Berbigier, P., Bernhofer, Ch., Clement, R., Elbers, J., Granier, A., Grünwald, T., Morgenstern, K., Pilegaard, K., Rebmann, C., Snijders, W., Velentini, R., and Vesala, T.: Estimates of the annual net carbon and water exchange of forests: The EUROFLUX methodology, Adv. Ecol. Res., 30, 113-175, 2000.

Aubinet, M., Chermanne, B., Vandenhaute, M., Longdoz, B., Yernaux, M., and Laitat, E.: Long-term carbon dioxide exchange above a mixed forest in the Belgian Ardennes, Agr. Forest Meteorol., 108, 293-315, 2001.

Baldocchi, D. D., Hincks, B. B., and Meyers, T. P.: Measuring biosphere-atmosphere exchanges of biologically related gases with micrometeorological methods, Ecology, 69, 1331-1340, 1988.

Baldocchi, D. D.: Assessing the eddy covariance technique for evaluating carbon dioxide exchange rates of ecosystems: past, present and future, Glob. Change Biol., 9, 479-492, 2003.

Baldocchi, D. D., Xu, L., and Kiang, N.: How plant functionaltype, weather, seasonal drought and soil physical properties alter water and energy fluxes of an oak-grass savanna and an annual grassland, Agr. Forest Meteorol., 123, 13-39, 2004.

Beringer, J., Chapin III, F. S., Thompson, C. C., and McGuire, A. D.: Surface energy exchanges along a tundra-forest transition and feedbacks to climate, Agr. Forest Meteorol., 131, 143-161, 2005.

Bunce, J. A.: Responses of stomatal conductance to light, humidity and temperature in winter wheat and barley grown at three concentrations of carbon dioxide in the field, Glob. Change Biol., 6, 371-382, 2000.

Foken, T. and Wichura, B.: Tools for quality assessment of surfacebased flux measurements, Agr. Forest Meteorol., 78, 83-105, 1996.

Forster, P., Ramaswamy, V., Artaxo, P., Berntsen, T., Betts, R., Fahey, D. W., Haywood, J., Lean, J., Lowe, C. C., Myhre, G., Nganga, J., Prinn, R., Raga, G., Schulz, M., and Van Dorland, R.: Changes in Atmospheric Constituents and in Radiative Forcing, in: Climate Change 2007: The Physical Science Basis, Contribution of Working Group I to the Fourth Assessment Report of the Intergovernmental Panel on Climate Change, edited by: Solomon, S., Qin, D., Manning, M., Chen, Z., Marquis, M., Averyt, K. B., Tignor, M. and Miller, H. L., Cambridge University Press, Cambridge, United Kingdom and New York, NY, USA, 2007.

Freedman, J. M., Fitzjarrald, D. R., Moore, K. E., and Sakai, R. K.: Boundary layer clouds and vegetation-atmosphere feedbacks, J. Climate, 14, 180-197, 2001.

Gholz, H. L. and Clark, K. L.: Energy exchange across a chronosequence of of slash pine forests in Florida, Agr. Forest Meteorol., 112, 87-102, 2002.

Goldberg, V. and Bernhofer, Ch.: Quantifying the coupling degree between land surface and the atmospheric boundary layer with the coupled vegetation-atmosphere model HIRVAC, Ann. Geophys., 19, 581-587, 2001, http://www.ann-geophys.net/19/581/2001/.

Goudriaan, J.: Crop micrometeorology: A simulation study, Wageningen: Pudoc., 249 pp., 1977. 
Granier, A., Bréda, N., Biron, P., and Villette, S.: A lumped water balance model to evaluate duration and intensity of drought constraints in forest stands, Ecol. Model., 116, 269-283, 1999.

Granier, A., Reichstein, M., Bréda, N., Janssens, I. A., Falge, E., Ciais, P., Grünwald, T., Aubinet, M., Berbigier, P., Bernhofer, Ch., Buchmann, N., Facini, O., Grassi, G., Heinesch, B., Ilvesniemi, H., Keronen, P., Knohl, A., Köstner, B., Lagergren, F., Lindroth, A., Longdoz, B., Loustau, D., Mateus, J., Montagnani, L., Nys, C., Moors, E., Papale, D., Peiffer, M., Pilegaard, K., Pita, G., Pumpanen, J., Rambal, S., Rebmann, C., Rodrigues, A., Seufert, G., Tenhunen, J., Vesala, T., and Wang, Q.: Evidence for soil water control on carbon and water dynamics in European forests during the extremely dry year: 2003, Agr. Forest Meteorol., 143, 123-145, 2007.

Grant, R. F., Zhang, Y., Yuan, F., Wang, S., Hanson, P. J., GaumontGuay, D., Chen, J., Black, T. A., Barr, A., Baldocchi, D. D., and Arain, A.: Intercomparison of techniques to model water stress effects on $\mathrm{CO}_{2}$ and energy exchange in temperate and boreal deciduous forests, Ecol. Model., 196, 189-312, 2006.

Gu, L., Meyers, T., Pallardy, S. G., Hanson, P. J., Yang, B., Heuer, M., Hosman, K. P., Riggs, J. S., Sluss, D., and Wullschleger, S. D.: Direct and indirect effects of atmospheric conditions and soil moisture on surface energy partitioning revealed by a prolonged drought at a temperate forest site, J. Geophys. Res., 111, D16102, doi:10.1029/2006JD007161, 2006.

Hall, R. L.: Aerodynamic resistance of coppiced poplar, Agr. Forest Meteorol., 114, 83-102, 2002.

Hao, Y., Wang, Y., Huang, X., Cui, X., Zhou, X., Wang, S., Niu, H., and Jiang, G.: Seasonal and interannual variation in water vapour and energy exchange over a typical steppe in Inner Mongolia, China, Agr. Forest Meteorol., 146, 57-69, 2007.

Hillel, D.: Fundamentals of soil physics, Academic Press, New York, 413 pp., 1980.

Hsieh, C.-I., Katul, G., and Chi, T.-W.: An approximate analytical model for footprint estimation of scalar fluxes in thermally stratified atmospheric flows, Adv. Water Resour., 23, 765-772, 2000.

Huang, X. and Lyons, T. J.: The simulation of surface heat fluxes in a land surface-atmosphere model, J. Appl. Meteorol., 34, 10991111,1995

Iritz, Z. and Lindroth, A.: Energy partitioning in relation to leaf area development of short-rotation willow coppice, Agr. Forest Meteorol., 81, 119-130, 1996.

Jarvis, P. G. and McNaughton, K. G.: Stomatal control of transpiration: scaling up from leaf to region, Adv. Ecol. Res., 15, 1-49, 1986.

Kaimal, J. C. and Finnigan, J. J.: Atmospheric boundary layer flows, Oxford University Press, Oxford, 289 pp., 1994.

Körner, Ch.: Evapotranspiration und Transpiration verschiedener Pflanzenbestände im alpinen Grasheidegürtel der Hohen Tauern, in: Alpine Grasheide Hohe Tauern, Ergebnisse der Ökosystemstudie 1976, Veröffentlichungen des österreichischen MaB Hochgebigsprogramms Hohe Tauern Vol. 1, edited by: Cernusca, A., Universitätsverlag Wagner Innsbruck, 47-68, 1977.

Larcher, W.: Ökophysiologie der Pflanzen, 6. Aufl., UTB, Stuttgart, 408 pp., 2001.
Li, S.-G., Harazono, Y., Oikawa, T., Zhao, H. L., He, Z. Y. and Chang, X. L.: Grassland desertifaction by grazing and the resulting micrometeorological changes in Inner Mongolia, Agr. Forest Meteorol., 102, 125-137, 2000.

Li, S.-G., Lai, C.-T., Lee, G., Shimoda, S., Yokoyama, T., Higuchi, A. and Oikawa, T.: Evapotranspiration from a wet temperate grassland and ist sensitivity to microenvironmental variables, Hydrol. Process., 19, 517-532, 2005.

Li, S.-G., Eugster, W., Asanuma, J., Kotani, A., Davaa, G., Oyunbaatar, D., and Sugita, M.: Energy partitioning and its biophysical controls above a grazing steppe in central Mongolia, Agr. Forest Meteorol., 137, 89-106, 2006.

Li, S.-G., Asanuma, J., Kotani, A., Davaa, G. and Oyunbaatar, D.: Evapotranspiration from a Mongolian steppe under grazing and its environmental constraints, J. Hydrol., 333, 133-143, 2007.

Mahfouf, J. F. and Noilhan, J.: Comparative study of various formulations of evaporation from bare soil using in situ data, J. Appl. Meteorol., 30, 1354-1365, 1991.

Massman, W. J.: An analytical one-dimensional model of momentum transfer by vegetation of arbitrary structure, Bound.-Lay. Meteorol., 83, 407-421, 1997.

Matsumoto, K., Ohta, T. and Tanaka, T.: Dependence of stomatal conductance on leaf chlorophyll concentration and meteorological variables, Agr. Forest Meteorol., 132, 44-57, 2005.

McMillen, R. T.: An eddy correlation system with extended applicability to non-simple terrain, Bound.-Lay. Meteorol., 43, 231245, 1988 .

Meyers, T. P.: A comparison of summertime water and $\mathrm{CO}_{2}$ fluxes over rangeland for well watered and drought conditions, Agr. Forest Meteorol., 106, 205-214, 2001.

Miller, G. R., Baldocchi, D. D., Law, B. E., and Meyers, T.: An analysis of soil moisture dynamics using multi-year data from a network of micrometeorological observation sites, Adv. Water Resour., 30, 1065-1081, 2007.

Monteith, J. L. and Unsworth, M. H.: Principles of environmental physics, 2nd edn., Routledge, Chapman and Hall Inc., New York, 291 pp., 1990.

Mooney, H. A., Field, C., Vasquez Yanes, C. and Chu, C.: Environmental controls on stomatal conductance in a shrub of the humid tropics, P. Natl. Acad. Sci. USA, 80, 1295-1297, 1983.

Moore, J. C.: Frequency response corrections for eddy correlation systems, Bound.-Lay. Meteorol., 37, 17-35, 1986.

Novick, K. A., Stoy, P. C., Katul, G. G., Ellsworth, D. S., Siqueira, M. B. S., Juang, J., and Oren, R.: Carbon dioxide and water vapour exchange in a warm temperate grassland, Oecologia, 138, 259-274, 2004.

Oguntunde, P. G. and van de Giesen, N.: Crop growth and development effects on surface albedo for maize and cowpea fields in Ghana, West Africa, Int. J. Biometeorol., 49, 106-112, 2004.

Oke, T. R.: Boundary layer climates, Routledge, London/New York, 435 pp., 1987.

Pan, H.-L. and Mahrt, L.: Interaction between soil hydrology and boundary-layer development, Bound.-Lay. Meteorol., 38, 185202, 1987.

Pielke, R. A.: Influence of the spatial distribution of vegetation and soils on the prediction of cumulus convective rainfall, Rev. Geophys., 39, 151-177, 2001. 
Ray, D. K., Nair, U. S., Welch, R. M., Han, Q., Zeng, J., Su, W., Kikuchi, T., and Lyons, T. J.: Effects of land use in Southwest Australia: 1. Observations of cumulus cloudiness and energy fluxes, J. Geophys. Res., 108(D14), 4414, doi:10.1029/2002JD002654, 2003.

Raupach, M. R.: Drag and drag partition on rough surfaces, Bound.Lay. Meteorol., 60, 375-395, 1992.

Ross, J.: Radiative transfer in plant communities, in: Vegetation and the atmosphere, Volume 1 principles, edited by: Monteith, J. L., Academic press, London, 13-55, 1981.

Rosset, M., Riedo, M., Grub, A., Geissmann, M., and Fuhrer, J.: Seasonal variation in radiation and energy balances of permanent pastures at different altitudes, Agr. Forest Meteorol., 86, 245258, 1997.

Rosset, M., Montani, M., Tanner, M., and Fuhrer, J.: Effects of abandonment on the energy balance and evapotranspiration of wet subalpine grassland, Agr. Ecosyst. Environ., 86, 277-286, 2001

Rutter, A. J.: The hydrological cycle in vegetation, in: Vegetation and Atmosphere, edited by: Monteith J. L., Academic Press London, New York, San Francisco, 179-185, 1975.

Saigusa, N., Oikawa, T., and Liu, S.: Seasonal variations of the exchange of $\mathrm{CO}_{2}$ and $\mathrm{H}_{2} \mathrm{O}$ between a grassland and the atmosphere: An experimental study, Agr. Forest Meteorol., 89, 131139, 1998.

Santanello Jr., J. A. and Friedl, M. A.: Diurnal covariation in soil heat flux and net radiation, J. Appl. Meteorol., 42, 851-862, 2003.

Sauer, T. J. and Horton R.: Soil Heat Flux, in: Micrometerology in Agricultural Systems, edited by: Viney, M. K., American Society of Agronomy, Inc., Crop Science Society of America, Inc., Soil Science Society of America, Inc. Publishers, Madison, 131-154, 2005.

Schneider, N. and Eugster, W.: Historical land use changes and mesoscale summer climate on the Swiss Plateau, J. Geophys. Res., 110, D19102, doi:10.1029/2004JD005215, 2005.

Schotanus, P., Nieuwstadt, F. T. M. and DeBruin, H. A. R.: Temperature measurement with a sonic anemometer and its application to heat and moisture fluctuations, Bound.-Lay. Meteorol., 26, 81-93, 1983.

Schulze, E.-D., Kelliher, F. M., Körner, C., Lloyd, J., Hollinger, D. J., and Vygodskaya, N. N.: The role of vegetation in controlling carbon dioxide and water exchange between land surface and the atmosphere, in: Global Change and terrestrial Ecosystems, edited by: Walker, B. and Steffen, W., Cambridge University Press, Cambridge, IGBP-Series 2, 77-92, 1996.

Shen, Y., Zhang, Y., Kondoh, A., Tang, Ch., Chen, J., Xiao, J., Sakura, Y., Liu, Ch., and Sun, H.: Seasonal variation of energy partitioning in irrigated lands, Hydrol. Process., 18, 2223-2234, 2004.

Song, J., Willmott, C. J., and Hanson, B.: Simulating the surface energy budget over the Konza Prairie with a mesoscale model, Agr. Forest Meteorol., 87, 105-118, 1997.

Song, J.: Phenological influences on the albedo of prairie grassland and crop fields, Int. J. Biometeorol., 42, 153-157, 1999.

Thom, A. S.: Momentum absorption by vegetation, Q. J. Roy. Meteor. Soc., 97, 414-428, 1971.
Twine, T. E., Kustas, W. P., Norman, J. M., Cook, D. R., Houser, P. R., Meyers, T. P., Prueger, J. H., Starks, P. J., and Wesely, M. L.: Correcting eddy-covariance flux underestimates over a grassland, Agr. Forest Meteorol., 103, 279-300, 2000.

Valentini, R., Gamon, J. A., and Field, Ch. B.: Ecosystem gas exchange in a California grassland: Seasonal patterns and implications for scaling, Ecology, 76, 1940-1952, 1995.

Wever, L., Flanagan, L. B., and Carlson, P. J.: Seasonal and interannual variation in evapotranspiration, energy balance and surface conductance in a northern temperate grassland, Agr. Forest Meteorol., 112, 31-49, 2002.

Wilson, K. B. and Baldocchi, D. D.: Seasonal and interannual variability of energy fluxes over a broadleaved temperate deciduous forest, Agr. Forest Meteorol., 100, 1-18, 2000.

Wilson, K. B., Baldocchi, D. D., Aubinet, M., Berbigier, P., Bernhofer, Ch., Dolman, H., Falge, E., Field, Ch., Goldstein, A., Granier, A., Grelle, A., Halldor, T., Hollinger, D., Katul, G., Law, B. E., Lindroth, A., Meyers, T., Moncrieff, J., Monson, R., Oechel, W., Tenhunen, J., Valentini, R., Verma, S., Vesala, T., and Wofsy, S.: Energy partitioning between latent and sensible heat flux during the warm season at FLUXNET sites, Water Resour. Res., 38, 1294, doi:10.1029/2001WR000989, 2002a.

Wilson, K. B., Goldstein, A. H., Falge, E., Aubinet, M., Baldocchi, D., Berbigier, P., Bernhofer, Ch., Ceulemans, R., Dolman, H., Field, C., Grelle, A., Law, B., Meyers, T., Moncrieff, J., Monson, R., Oechel, W., Tenhunen, J., Valentini, R., and Verma, S.: Energy balance closure at FLUXNET sites, Agr. Forest Meteorol., 113, 223-243, 2002b.

Wilson, K. B., Baldocchi, D. D., Falge, E., Aubinet, M., Berbigier, P., Bernhofer, Ch., Dolman, H., Field, C., Goldstein, H., Granier, A., Hollinger, D., Katul, G., Law, B. E., Meyers, T., Moncrieff, J., Monson, R., Tenhunen, J., Valentini, R., Verma, S., and Wofsy, S.: The diurnal centroid of ecosystem energy and carbon fluxes at FLUXNET sites, J. Geophys. Res., 108(D21), 4664, doi:10.1029/2001JD001349, 2003.

Wohlfahrt, G., Bahn, M., and Cernusca, A.: The use of the ratio between the photosynthesis parameters $\mathrm{P}_{m l}$ and $\mathrm{V}_{C \max }$ for scaling up photosynthesis of $\mathrm{C}_{3}$ plants from leaves to canopies, $\mathrm{A}$ critical examination of different modelling approaches, J. Theor. Biol., 200, 163-181, 1999.

Wohlfahrt, G., Sapinsky, S., Tappeiner, U., and Cernusca, A.: Estimation of plant area index of grasslands from measurements of canopy radiation profiles, Agr. Forest Meteorol., 109, 1-12, 2001.

Wohlfahrt, G. and Cernusca, A.: Momentum transfer by a mountain meadow canopy: a simulation analysis based on Massman's (1997) model, Bound-Lay. Meteorol., 103, 391-407, 2002.

Wohlfahrt, G., Anfang, Ch., Bahn, M., Haslwanter, A., Newesely, Ch., Schmitt, M., Drösler, M., Pfadenhauer, J., and Cernusca, A.: Quantifying nighttime ecosystem respiration of a meadow using eddy covariance, chambers and modelling, Agr. Forest Meteorol., 128, 141-162, 2005.

Yang, Z.-L., Dai, Y., Dickinson, R. E. and Shuttleworth, W. J.: Sensitivity of ground heat flux to vegetation cover fraction and leaf area index, J. Geophys. Res., 104, 19505-19514, 1999. 